\title{
SISTEM GANJIL GENAP PADA PINTU TOL TAMBUN TERHADAP KEMACETAN LALU LINTAS DI TOL JAKARTA-CIKAMPEK
}

\author{
Muhamad Fauzi RAKHMAN, Sri NURYATI*, Anita Setyowati Srie GUNARTI \\ Program Studi Teknik Sipil, Universitas Islam 45, Jl. Cut Meutia No. 83 Bekasi, Indonesia \\ *Email Korespondensi: srinuryati45ft@gmail.com \\ [diterima: 20 April 2020, disetujui: 22 Juni 2020]
}

\begin{abstract}
Control of vehicles with even-odd license plate numbers entering the Tambun Toll Gate has begun on 3 December 2018, for vehicles from Bekasi to Jakarta, as an effort by the government to reduce congestion. This study aims to determine the effect of the application of even-odd systems on the Tambun Toll Gate to the decrease of the traffic volume and the increase of vehicle speed at the Jakarta-Cikampek toll road. A field survey is used to calculate the amount of traffic volume. Vehicle speeds on the Cibitung-Bekasi Timur toll road are carried out using the individual speed survey method. The results showed that the application of the even plate system of vehicles at the Tambun Toll Gate could reduce the volume of vehicles by $43.09 \%$. By using the individual speed survey method, it can be seen that the increase in vehicle speed on the Cibitung-Bekasi Timur toll road is $7.62 \%$.
\end{abstract}

Keywords: Vehicle Plates, Vehicle Volume, Vehicle Speed, Individual Speed, Tambun Toll Gate.

\section{INTISARI}

Pengaturan sistem ganjil genap pelat kendaraan di Gerbang Tol Tambun mulai diberlakukan pada tanggal 03 Desember 2018 bagi kendaraan dari arah Bekasi menuju Jakarta, sebagai upaya pemerintah dalam menurunkan angka kemacetan. Penelitian ini bertujuan untuk mengetahui besar pengaruh penerapan sistem ganjil genap pada Gerbang Tol Tambun terhadap penurunan jumlah volume lalu lintas dan kenaikan kecepatan kendaraan di tol Jakarta-Cikampek. Metode yang digunakan yaitu survei lapangan untuk menghitung jumlah volume lalu lintas. Kecepatan kendaraan pada ruas tol Cibitung-Bekasi Timur dilakukan dengan metode survei individu (individual speed). Hasil penelitian menunjukkan penerapan sistem ganjil genap pelat kendaraan pada Gerbang Tol Tambun dapat mengurangi volume kendaraan sebesar 43,09\%. Berdasarkan metode survei individual speed, dapat diketahui bahwa kenaikan kecepatan kendaraan pada ruas tol Cibitung-Bekasi Timur sebesar 7,62\%.

Kata kunci: Pelat Kendaraan, Volume Kendaraan, Kecepatan Kendaraan, Individual Speed, Gerbang Tol Tambun.

\section{PENDAHULUAN}

Peningkatan angka pertumbuhan lalu lintas yang terus meningkat setiap tahunnya yang tidak sebanding dengan peningkatan jumlah sarana transpostasi menyebabkan kemacetan yang tidak dapat dihindari terutama di wilayah Jabodetabek dan wilayah kawasan industri. Pertambahan kendaraan bermotor setiap tahun tidak diimbangi dengan penambahan ruas jalan berdampak terhadap menurunnya kinerja jalan (Maarif, 2019). Peningkatan pergerakan akan berdampak pada sarana prasarana transportasi yang terus ditingkatkan dalam baik dalam segi kualitasi fisik ataupun kualitas pelayanan (Putra, 2018). Berdasarkan Survei Jabodetabek Urban Transportation Policy Integration (JUTPI), 
hanya sekitar 27\% masyarakat di Jakarta yang melakukan perjalanan dengan transportasi umum (Hutauruk, 2017). Hal tersebut menyebabkan peningkatan jumlah kendaraan pribadi setiap tahunnya, sehingga kemacetan lalu lintas termasuk pada jalan bebas hambatan atau jalan tol terutama pada jam-jam sibuk pagi dan sore, salah satunya adalah jalan tol Jakarta-Cikampek (Japek).

Kemacetan di ruas tol Japek disebabkan oleh pekerjaan pembangunan LRT CawangBekasi Timur, Kereta Cepat Jakarta-Bandung dan Tol Jakampek Elevated. Kebijakan pemerintah untuk mengurangi kemacetan pada tol Japek (Kementrian Perhubungan, 2018) tentang Pengaturan Lalu Lintas Selama Masa Pembangunan Proyek Infrastruktur Strategis Nasional Di Ruas Jalan Tol Jakarta Cikampek adalah dengan memberlakukan sistem ganjil genap pelat kendaraan pada hari kerja (SeninJum'at) dari jam 06.00 sampai 09.00 WIB bagi kendaraan dari arah Bekasi menuju Jakarta, yang melalui Gerbang Tol (GT) Bekasi Barat dan Bekasi Timur. Menurut Direktur Lalu Lintas dan Angkutan Badan Pengelola Transportasi Jabodetabek Karlo Manik, penurunan kendaraan yang melintasi gerbang Tol Bekasi Barat arah Jakarta selama penerapan sistem ganjil genap turun sekitar 30 persen dari yang sebelumnya 2.600 kendaraan menjadi 1.620 (Medcom.id, 2018). Khafian (2014) menyarankan upaya jangka panjang masalah transportasi di Jakarta melalui integrasi kebijakan tata ruang dengan kebijakan transportasi serta pembentukan otoritas khusus transportasi Jabodetabek. Heilmann, dkk (2011) melakukan penggabungan data dari berbagai sumber untuk meningkatkan estimasi dan akurasi prediksi kondisi lalu lintas di jalan raya terhadap dua studi kasus pada bagian jalan raya intraurban dan jalan tol antar kota di Austria

Mutharuddin (2013) meneliti mengenai dampak penerapan kebijakan kendaraan berplat ganjil genap terhadap kinerja lalu lintas. Penelitian tersebut memberikan hasil bahwa jumlah mobil pribadi yang memiliki plat ganjil, lebih banyak dari jumlah kendaraan pribadi yang berplat genap yaitu $54,5 \%$ (ganjil) dan $44,5 \%$ (genap). Volume lalu lintas mengalami penurunan 12\% (1.966 smp/jam) apabila plat ganjil tidak diperbolehkan dan $\quad 9 \% \quad(2.109 \quad$ smp/jam $)$ apabila plat genap tidak diperbolehkan melintasi ruas jalan tersebut. Kecepatan awal pada ruas jalan tersebut meningkat dari 28 $\mathrm{km} / \mathrm{jam}$ menjadi $36,5 \mathrm{~km} / \mathrm{jam}$ untuk larangan plat genap dan $38 \mathrm{~km} / \mathrm{jam}$ untuk larangan plat ganjil melintas.

Martini (2012) memberikan kesimpulan bahwa penerapan system plat nomor ganjil/genap ini baik diterapkan dengan syarat bahwa selain sistem ini dilaksanakan, adapun infrastruktur seperti jalan, transportasi umum harus dikembangkan dan dipantau mengenai kondisi kendaraan.

Berdasarkan keberhasilan penerapan ganjil genap di gerbang tol tersebut maka sistem ganjil genap ini juga akan diberlakukan di gerbang tol Tambun pada tanggal 3 Desember 2018. Tujuan diterapkannya sistem ganjil genap di gerbang tol Tambun adalah untuk lebih meningkatkan efektivitas pemberlakuan kebijakan ganjil genap dalam mengurai kepadatan lalu lintas pada Jalan Tol Japek.

Penelitian ini melakukan evaluasi pengaruh pemberlakuan sistem ganjil genap di Gerbang Tol Tambun terhadap kemacetan di Jalan Tol Japek untuk arah Jakarta. Evaluasi yang dilakukan meliputi perhitungan jumlah volume kendaraan yang bertujuan untuk menghitung jumlah penurunan kendaraan serta menghitung kecepatan kendaraan pada jalan tol Japek arah Jakarta khususnya pada ruas Cibitung-Tambun dan Tambun-Bekasi Timur untuk mengetahui kenaikan kecepatan ratarata kendaraan pada ruas jalan tersebut yang dilakukan selama 5 hari pada hari kerja yaitu hari Senin sampai Jum'at pada pukul 06-00 sampai 09.00 WIB. Tujuan dari penelitian ini 
yaitu untuk mengetahui besarnya pengaruh terhadap kemacetan lalu lintas di Jalan tol Japek arah Jakarta.

\section{METODOLOGI PENELITIAN}

Gerbang Tol Tambun seperti terlihat pada Gambar 1 yaitu terdiri dari 5 gardu untuk masuk tol Jakarta Cikampek dan 4 gardu untuk keluar dari tol Jakarta Cikampek. Bagi kendaraan yang ingin melakukan perjalanan melalui tol ke arah Jakarta disediakan 4 gardu masuk tol ke arah Jakarta. Untuk kendaraan yang masuk tol Tambun ke arah Cikampek disediakan 1 gardu tol. Titik dan area lokasi pengamatan survei ditunjukan pada Gambar 2.

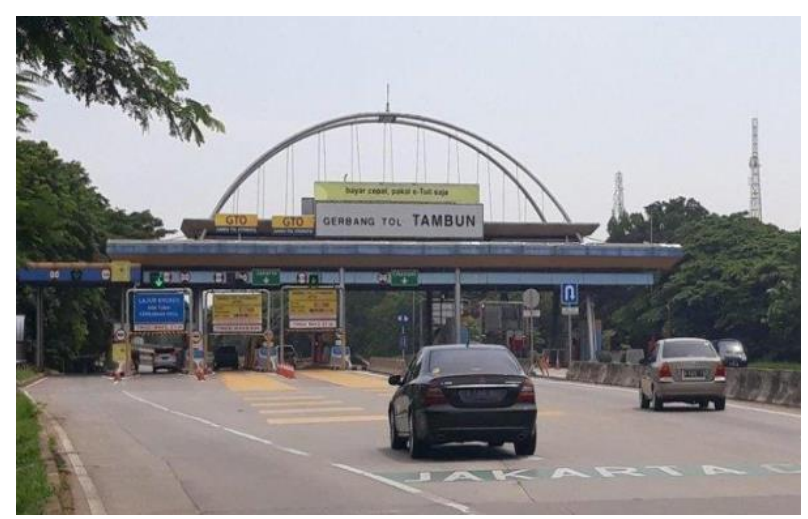

Sumber: Data Pribadi, 2018

Gambar 1. Gerbang Tol Tambun

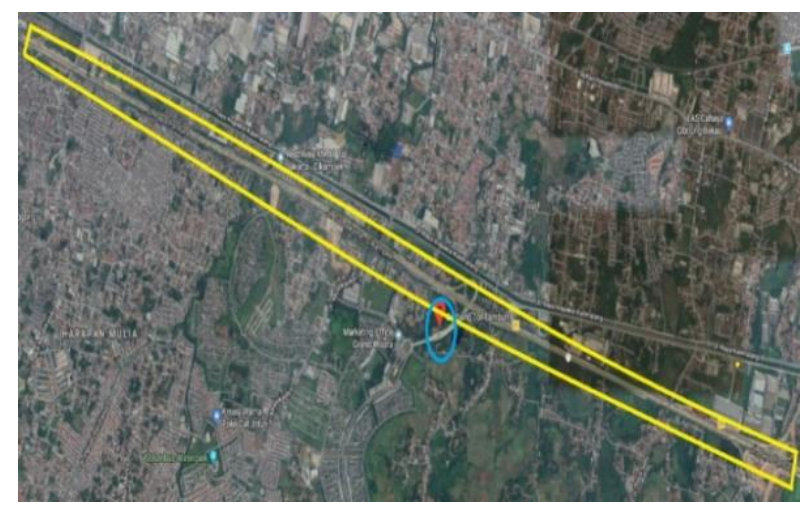

Sumber: Google Maps, 2018

Catatan: Warna biru adalah lokasi survei menghitung jumlah kendaraan Warna kuning adalah lokasi survei menghitung kecepatan kendaraan

Gambar 2. Titik dan Area Lokasi Pengamatan berikut: sistem ganjil-genap pada Pintu Tol Tambun a. Waktu Pengamatan

Survei dilakukan selama 5 hari kerja yaitu Senin hingga Jum'at pada tanggal 17 Desember 2018 sampai 21 Desember 2018 jam 06.00 hingga 09.00 WIB atau pada saat penerapan sistem ganjil-genap Survei ini mencatat data Jumlah volume kendaraan arah tol Jakarta yang masuk melalui gerbang tol Tambun setelah diberlakukan sistem ganjil-genap. Survei untuk mendapatkan data kecepatan kendaraan di jalan tol Jakarta Cikampek arah Jakarta di sekitar tol Tambun dilakukan selama 2 hari kerja pada tanggal 17 dan 20 Desember 2018 dengan metode individual speed menggunakan form survei dari PT. Jasa Marga.

Jenis kendaraan yang di survei adalah semua kendaraan yang masuk ke tol Jakarta Cikampek arah Jakarta yang melalui pintu tol Tambun.

b. Metode Survei

Pengamatan menggunakan Metode survei langsung di lapangan untuk menghitung volume kendaraan. Sedangkan untuk menghitung kecepatan kendaraan menggunakan metode individual speed. Hasil survei diolah dengan menggunakan aplikasi Microsoft Excel.

c. Lokasi Pengamatan

Pencatatan jumlah kendaraan dilakukan di pintu Gerbang Tol Tambun. Pencatatan kecepatan kendaraan dilakukan di sepanjang jalan dari Tol Cibitung hingga Tol Bekasi Timur.

\section{HASIL DAN PEMBAHASAN}

\section{Volume Lalu Lintas}

Untuk mengetahui pengaruh sistem ganjil-genap pada pintu tol Tambun terhadap kemacetan lalu lintas jalan tol JakartaCikampek arah Jakarta dilakukan 
perbandingan besar volume lalu lintas kendaraan yang diuraikan berikut ini.

Tabel 1 menunjukkan bahwa jumlah volume kendaraan yang paling banyak terdapat pada hari Rabu, 14-11-2018 yaitu sebanyak 1.921 kendaraan, sedangkan jumlah kendaraan yang paling sedikit terdapat di hari Kamis, 15-11-2018 dan Jum'at 16-11-2018 yaitu sebanyak 1.373 kendaraan dan 1.398 kendaraan. Grafik jumlah volume kendaraan dapat dilihat pada Gambar 3.

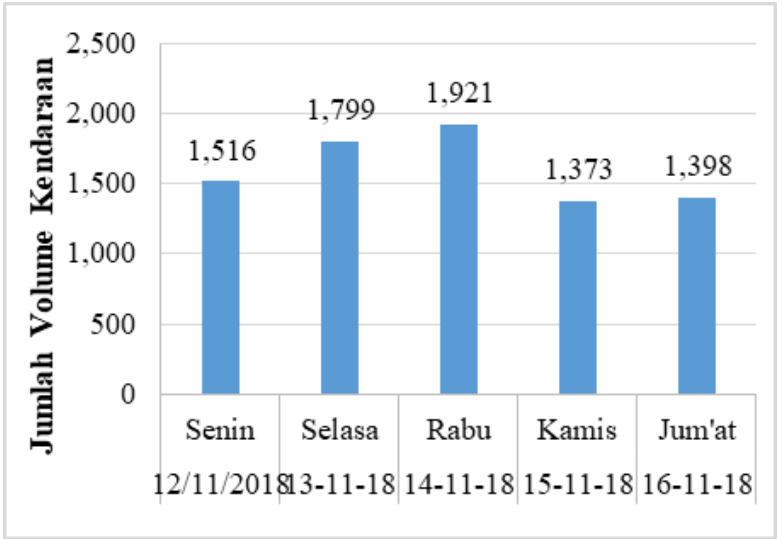

Gambar 3. Grafik Jumlah Volume Lalu Lintas Sebelum Sistem Ganjil Genap

\section{Volume Lalu Lintas Setelah Penerapan Sistem Ganjil Genap}

Jumlah volume lalu lintas setelah penerapan sistem ganjil genap ditunjukan pada Tabel 2. Tabel 2 dan Gambar 4 menunjukkan bahwa jumlah volume kendaraan yang paling banyak terdapat pada hari Jum'at, 21-12-2018 yaitu sebanyak 1.224 kendaraan, sedangkan pada hari Senin, 17-12-2018 sampai dengan hari Kamis, 20-12-2018 jumlah volume kendaraan sekitar 800 sampai 900 kendaraan.

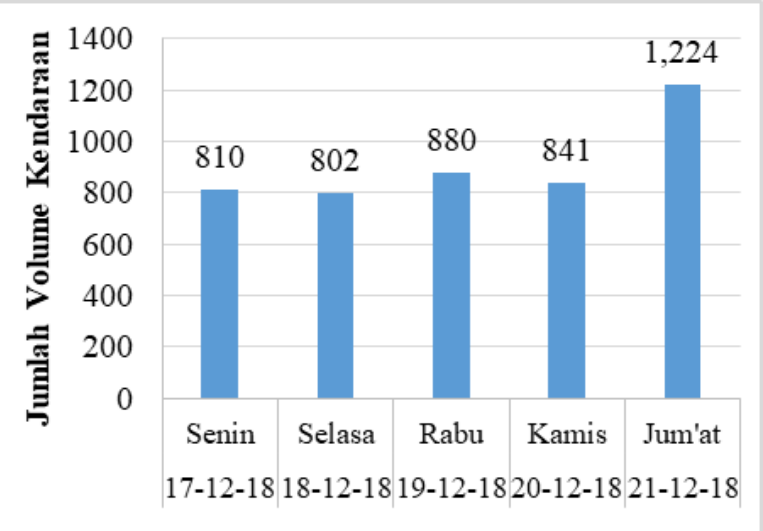

Gambar 4. Grafik Jumlah Volume Lalu Lintas Setelah Penerapan Sistem Ganjil Genap

Tabel 1. Jumlah Volume Lalu Lintas Sebelum Sistem Ganjil Genap

\begin{tabular}{crrrrr}
\hline & \multicolumn{5}{c}{ Hari, Tanggal } \\
\cline { 2 - 6 } Jam & \multicolumn{1}{c}{ Senin } & Selasa & Rabu & Kamis & Jum'at \\
& $12-11-2018$ & $13-11-2018$ & $14-11-2018$ & $15-11-2018$ & $16-11-2018$ \\
\cline { 2 - 6 } & \multicolumn{1}{c}{ Kend } & \multicolumn{1}{c}{ Kend } & Kend & Kend & Kend \\
\hline $06.00-06.59$ & 451 & 481 & 592 & 420 & 405 \\
$07.00-07.59$ & 539 & 676 & 727 & 486 & 495 \\
$08.00-08.59$ & 526 & 642 & 602 & 467 & 498 \\
\hline Jumlah Kendaraan & 1,516 & 1,799 & 1,921 & 1,373 & 1,398 \\
\hline Sumber: PT. Jasa Marga, 2018 & & & & &
\end{tabular}

Tabel 2. Volume Kendaraan Setelah Penerapan Sistem Ganjil Genap

\begin{tabular}{lrrrrr}
\hline & \multicolumn{5}{c}{ Hari, Tanggal } \\
\cline { 2 - 6 } Jam & \multicolumn{1}{c}{ Senin } & Selasa & Rabu & Kamis & \multicolumn{1}{c}{ Jum'at } \\
& \multicolumn{1}{c}{ Kend } & \multicolumn{1}{c}{ Kend } & \multicolumn{1}{c}{ Kend } & \multicolumn{1}{c}{ Kend } & \multicolumn{1}{c}{ Kend } \\
\cline { 2 - 7 } & \multicolumn{1}{c}{ Kend } & 266 & 231 & 233 & 360 \\
\hline $06.00-06.59$ & 234 & 216 & 271 & 279 & 429 \\
$07.00-07.59$ & 325 & 320 & 378 & 329 & 435 \\
$08.00-08.59$ & 810 & 802 & 880 & 841 & 1,224 \\
\hline Jumlah Kend & & & & &
\end{tabular}




\section{Hasil Perbandingan Volume Lalu Lintas}

Tabel 3 menunjukkan hasil perbandingan jumlah volume lalu lintas yang menggunakan tol Jakarta-Cikampek arah Jakarta yang melalui pintu tol tambun sebelum dan setelah penerapan sistem ganjil genap plat kendaraan.

Tabel 3 menunjukkan perbandingan jumlah volume lalu lintas selama 5 hari kerja pada saat sebelum dan setelah adanya penerapan sistem ganjil genap terjadi penurunan volume dari 8.007 kendaraan menjadi 4.557 kendaraan atau sebanyak 3.450 kendaraan.

Gambar 5 merupakan Grafik Presentase Penurunan Jumlah Volume Kendaraan Sebelum dan Setelah Penerapan Sistem Ganjil Genap. Berdasarkan Gambar 5 maka dapat dilihat bahwa jumlah volume kendaraan yang mengalami penurunan terbesar terjadi pada hari Selasa yaitu sebesar 55,42\%, sedangkan jumlah penurunan volume kendaraan terkecil terjadi pada hari Jum'at yaitu sebesar 12,45\%.

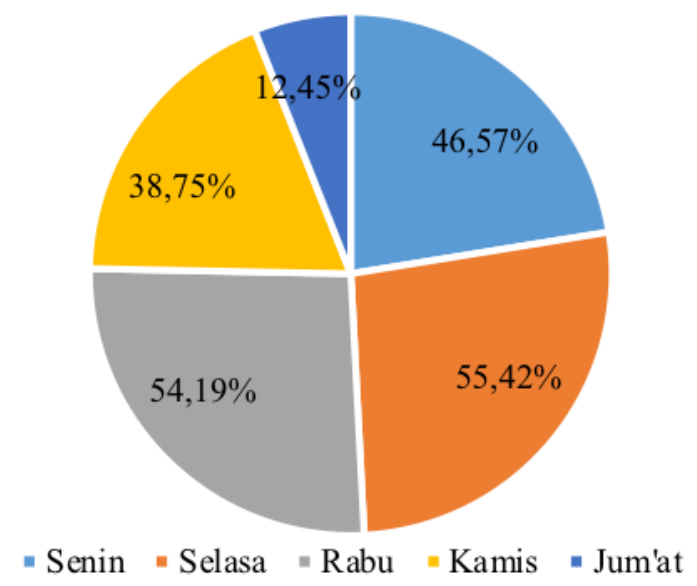

Gambar 5. Grafik Presentase Penurunan Jumlah Volume Kendaraan Sebelum dan Setelah Penerapan Sistem Ganjil Genap

Tabel 3. Hasil Perbandingan Jumlah Volume Lalu Lintas Sebelum dan Setelah Penerapan Sistem Ganjil Genap

\begin{tabular}{lrrrr}
\hline \multirow{2}{*}{ Hari } & \multicolumn{2}{c}{ Volume Kendaraan (Kend) } & Selisih & Persentase \\
\cline { 2 - 3 } & \multicolumn{1}{c}{$\begin{array}{c}\text { Sebelum } \\
(\text { Kend })\end{array}$} & $\begin{array}{c}\text { Setelah } \\
(\text { Kend })\end{array}$ & & \\
\hline Senin & 1,516 & 810 & 706 & 46,57 \\
Selasa & 1,799 & 802 & 997 & 55,42 \\
Rabu & 1,921 & 880 & 1,041 & 54,19 \\
Kamis & 1,373 & 841 & 532 & 38,75 \\
Jum'at & 1,398 & 1,224 & 174 & 12,45 \\
\hline Jumlah & 8,007 & 4,557 & 3,450 & 43,09 \\
\hline
\end{tabular}

\section{Kecepatan Lalu Lintas}

Perbandingan untuk mengetahui besar pengaruh sistem ganjil genap pada pintu tol Tambun terhadap kemacetan lalu lintas jalan tol Jakarta-Cikampek arah Jakarta dilakukan dengan membandingkan kecepatan kendaraan pada saat sebelum pemberlakuan sistem ganjil genap dan setelah pemberlakuan sistem ganjil genap.

\section{Kecepatan Lalu Lintas Sebelum Ganjil Genap}

Kecepatan lalu lintas sebelum penerapan sistem ganjil genap di dapatkan dari instansi terkait yaitu PT Jasa Marga. Berdasarkan Tabel 4 maka kecepatan rata-rata pada bulan November untuk ruas tol Cibitung sampai Tambun sebesar 36,64 Km/jam. Sedangkan kecepatan rata-rata untuk ruas tol Tambun sampai Bekasi Timur sebesar 31,32 Km/jam. Namun jika dihitung secara menyeluruh dari Cibitung sampai Bekasi Timur kecepatan rataratanya menjadi 33,98 Km/jam. Pada Bulan November kecepatan rata-ratanya belum mencapai target sebesar 35-45 Km/jam. 
Kecepatan Lalu Lintas Setelah Ganjil Genap

Hasil survei kecepatan kendaraan ditunjukan pada Tabel 5. Berdasarkan Tabel 5 maka kecepatan rata-rata pada bulan Desember untuk ruas tol Cibitung sampai Tambun sebesar 42,16 Km/jam. Sedangkan kecepatan rata-rata untuk ruas tol Tambun sampai Bekasi Timur sebesar 30,98 Km/jam. Namun jika dihitung secara menyeluruh dari Cibitung sampai Bekasi Timur kecepatan rataratanya menjadi sebesar $36,57 \mathrm{Km} / \mathrm{jam}$. Pada Bulan Desember kecepatan kendaraan sudah mencapai target sebesar 35-45 $\mathrm{Km} / \mathrm{jam}$.

Tabel 4. Kecepatan Kendaraan Sebelum Penerapan Sistem Ganjil Genap

\begin{tabular}{|c|c|c|c|c|c|c|c|c|c|}
\hline \multirow{3}{*}{ Tanggal } & \multirow{3}{*}{ Area } & \multirow{3}{*}{$\begin{array}{c}\text { Panjang } \\
\text { Ruas } \\
(\mathrm{Km})\end{array}$} & \multicolumn{6}{|c|}{ Waktu Tempuh } & \multirow{3}{*}{$\begin{array}{c}\mathrm{Kec} \\
(\mathrm{Km} / \mathrm{Jam})\end{array}$} \\
\hline & & & \multicolumn{3}{|c|}{ Keberangkatan } & \multicolumn{3}{|c|}{ Kedatangan } & \\
\hline & & & Jam & Mnt & Dtk & Jam & Mnt & Dtk & \\
\hline $12-11-2018$ & $\mathrm{C}-\mathrm{T}$ & 3.40 & 0 & 45 & 30 & 0 & 57 & 59 & 16.34 \\
\hline $15-11-2018$ & $\mathrm{C}-\mathrm{T}$ & 3.40 & 0 & 41 & 55 & 0 & 45 & 30 & 56.93 \\
\hline \multicolumn{9}{|c|}{ Kecepatan Rata-rata } & 36.64 \\
\hline $12-11-2018$ & T-BT & 4.50 & 0 & 57 & 59 & 1 & 19 & 5 & 12.80 \\
\hline $15-11-2018$ & T-BT & 4.50 & 0 & 45 & 30 & 0 & 50 & 55 & 49.85 \\
\hline \multicolumn{9}{|c|}{ Kecepatan Rata-rata } & 31.32 \\
\hline \multicolumn{9}{|c|}{$\begin{array}{c}\text { Kecepatan Rata-rata Keseluruhan } \\
\text { (Cibitung - Bekasi Timur) }\end{array}$} & 33.98 \\
\hline
\end{tabular}

Keterangan: C: Cibitung, T: Tambun, BT: Bekasi Timur

Tabel 5. Kecepatan Kendaraan Setelah Penerapan Sistem Ganjil Genap

\begin{tabular}{|c|c|c|c|c|c|c|c|c|c|}
\hline \multirow{3}{*}{ Tanggal } & \multirow{3}{*}{ Area } & \multirow{3}{*}{$\begin{array}{c}\text { Panjang } \\
\text { Ruas } \\
(\mathrm{Km})\end{array}$} & \multicolumn{6}{|c|}{ Waktu Tempuh } & \multirow{3}{*}{$\begin{array}{l}\mathrm{Kec} \\
(\mathrm{Km} \\
/ \mathrm{Jam})\end{array}$} \\
\hline & & & \multicolumn{3}{|c|}{ Keberangkatan } & \multicolumn{3}{|c|}{ Kedatangan } & \\
\hline & & & Jam & Mnt & Dtk & Jam & Mnt & Dtk & \\
\hline $19-12-2018$ & C-T & 3.40 & 7 & 56 & 29 & 8 & 4 & 35 & 25.19 \\
\hline $21-12-2018$ & C-T & 3.40 & 7 & 42 & 10 & 7 & 45 & 37 & 59.13 \\
\hline \multicolumn{9}{|c|}{ Kecepatan Rata-rata } & 42.16 \\
\hline $19-12-2018$ & $\mathrm{~T}-\mathrm{BT}$ & 4.50 & 7 & 4 & 35 & 8 & 15 & 57 & 23.75 \\
\hline $21-12-2018$ & $\mathrm{~T}-\mathrm{BT}$ & 4.50 & 7 & 45 & 37 & 7 & 52 & 41 & 38.21 \\
\hline \multicolumn{9}{|c|}{ Kecepatan Rata-rata } & 30.98 \\
\hline \multicolumn{9}{|c|}{$\begin{array}{l}\text { Kecepatan Rata-rata Keseluruhan } \\
\text { (Cibitung - Bekasi Timur) }\end{array}$} & 36.57 \\
\hline
\end{tabular}

Keterangan: C: Cibitung, T: Tambun, BT: Bekasi Timur

\section{Hasil Perbandingan Kecepatan Kendaraan}

Hasil perbandingan kecepatan kendaraan setelah penerapan sistem ganjil genap ditunjukkan pada Tabel 6. Berdasarkan Tabel 6 , kecepatan rata-rata pada bulan November dan Desember untuk ruas tol Cibitung sampai
Tambun mengalami peningkatan sebesar 5,52 $\mathrm{Km} / \mathrm{jam}$ atau sebesar $15,07 \%$, sedangkan kecepatan rata-rata untuk ruas tol Tambun sampai Bekasi Timur mengalami penurunan kecepatan sebesar $0,34 \mathrm{Km} / \mathrm{jam}$ atau turun sebesar $-1,09 \%$. Namun jika dihitung secara menyeluruh dari Cibitung sampai Bekasi 
Timur, kecepatan rata-rata mengalami peningkatan sebesar $2,59 \mathrm{Km} / \mathrm{jam}$ atau sebesar $7,62 \%$.

\section{KESIMPULAN}

Penerapan sistem ganjil genap pada Gerbang Tol Tambun efektif dalam mengurai kemacetan pada jalan tol Jakarta Cikampek arah Jakarta, terbukti dengan menurunnya jumlah volume lalu lintas sebesar 43,09\% dan meningkatnya kecepatan kendaraan sebesar 7,62\%. Jumlah volume kendaraan yang masuk gerbang tol Tambun bukan merupakan faktor utama yang mempengaruhi kecepatan kendaraan pada tol Jakarta Cikampek di ruas tol Cibitung-Tambun dan Tambun-Bekasi Timur karena volume kendaraan pada ruas tol
Cibitung-Tambun dan Tambun-Bekasi Timur adalah volume seluruh kendaraan yang masuk dari berbagai gerbang tol seperti Cibitung, Cikarang, Karawang dan Cikampek. Rekomendasi yang dapat diberikan antara lain yaitu hasil analisa efektivitas penerapan sistem ganjil genap pada pintu tol Tambun didapat beberapa saran yaitu: Perlunya pengawasan agar kendaraan yang masuk tol Tambun arah Jakarta adalah kendaraan yang sesuai dengan peraturan sistem ganjil genap pelat kendaraan, perlunya transportasi umum yang memadai agar para pengguna kendaraan pribadi beralih menggunakan kendaraan umum. Berdasarkan hasil penelitian dan analisis maka sistem ganjil genap dapat diperpanjang waktunya dari yang semula jam 06.00-09.00 menjadi jam 06.0010.00 .

Tabel 6. Hasil Perbandingan Kecepatan Kendaraan

\begin{tabular}{|c|c|c|c|c|}
\hline \multirow{2}{*}{ Area } & \multicolumn{2}{|c|}{ Kecepatan $(\mathrm{Km} / \mathrm{jam})$} & \multirow{2}{*}{ Selisih } & \multirow{2}{*}{$\begin{array}{c}\text { Prosentase } \\
(\%)\end{array}$} \\
\hline & Nov & Des & & \\
\hline C-T & 36.64 & 42.16 & 5.52 & 15.07 \\
\hline T-BT & 31.32 & 30.98 & -0.34 & -1.09 \\
\hline \multicolumn{5}{|c|}{ Keseluruhan } \\
\hline C-BT & 33.98 & 36.57 & 2.59 & 7.62 \\
\hline
\end{tabular}

Keterangan: C: Cibitung, T: Tambun, BT: Bekasi Timur

\section{DAFTAR PUSTAKA}

Heilmann, B., El Faouzi, N.E., de Mouzon, O., Hainitz, N., Koller, H., Bauer, D. and Antoniou, C., 2011. Predicting motorway traffic performance by data fusion of local sensor data and electronic toll collection data. Computer-Aided Civil and Infrastructure Engineering, 26(6), pp.451-463.

Hutauruk, D.M., 2017. Survei: Fasilitas Transportasi di Jakarta Buruk, URL (https://regional.kontan.co.id/news/surve i-fasilitas-transportasi-di-jakarta-buruk (diakses: 23 Mei 2018)
Kementrian Perhubungan, 2018, Keputusan Menteri Perhubungan Republik Indonesia Nomor PM 18 Tahun 2018.

Khafian, N., 2014. The efforts of handling transportation problems in DKI Jakarta through sustainable transportation policy. Bisnis \& Birokrasi Journal, 20(3).

Maarif, R., Nuryati, S. and Paryati, N., 2019. Kinerja Simpang Bersinyal Jalan Ahmad Yani dengan Jalan M. Hasibuan-Jalan KH. Noer Ali Kota Bekasi. BENTANG: Jurnal Teoritis dan Terapan Bidang Rekayasa Sipil, 7(1), pp.47-59.

Martini, E., 2012. Pengamatan Tentang Penerapan Sistem Plat Nomor 
Ganjil/Genap sebagai Alternatif

Pengurangan Kepadatan Kendaraan

Pribadi di Jalan Raya. Planesa, 3(1).

Medcom.id, 2018, Kemacetan di Tol JakartaCikampek di Klaim Menurun, URL https://www.medcom.id/nasional/metro/ MkMMwERk-kemacetan-di-tol-jakartacikampek-diklaim-menurun (diakses 23 Mei 2018)

Mutharuddin, M. And Herawati, H., 2013. Dampak Penerapan Kebijakan Kendaraan Berplat Ganjil Genap
Terhadap Kinerja Lalu Lintas (Studi Kasus: Pergerakan Kendaraan Bermotor dari Bekasi Menuju DKI Jakarta). Jurnal Penelitian Transportasi Darat, 15(1), Pp.01-13.

Putra, R.A.E. and Ramanda, F., 2018. Optimasi Green Time Simpang Bersinyal dengan Menggunakan Ptv Vissim dalam Meningkatkan Kinerja Simpang. BENTANG: Jurnal Teoritis dan Terapan Bidang Rekayasa Sipil, 6(2), pp.108-117. 